\title{
Towards a Narrow Bridge: A Critical Overview of the Operating Environment for Civil Society Organisations in Uganda
}

\author{
Edrine Wanyama*
}

\begin{abstract}
Civil society plays an important role in checking government excesses. It is necessary for accountable and transparent governance. Nevertheless, the environment in which civil society operates across the globe is constantly shrinking. This paper provides for a brief history of stages of development of civil society in Uganda and a brief outline of the numbers of civil society organisations from inception. The paper asserts that the factors affecting the operating environment for civil society are both external and internal. The external factors include: perception of civil society as partisan, restrictive legal environment which mainly consists of the Non-Governmental Organisations Act, 2016, the Public Order Management Act, 2013, the Anti-Terrorism Act, 2005 as amended 2015, the Anti-Pornography Act, 2014, the Anti-Money Laundering Act, 2014; security and safety; reliance on donor funding and ignorance of the public due to information gaps. The internal factors include: noncompliance with legal requirements and internal governance issues. The paper concludes that civil society is partly to blame for the shrinking Civil Society Organisations (CSO) space. Finally, the paper notes that for civil society to survive amidst the shrinking political and civic space, capacity development as well as compliance with the laws by CSOs is necessary if they are cope with the emerging security threats. Further, there must be adoption and strengthening of security, cooperation and solidarity, delving into alternative sources of funding, co-operating with government and efforts geared towards amendment of restrictive legislation.
\end{abstract}

\section{A. Introduction}

Civil society Organisations (CSOs) consists of Non-Governmental Organisations (NGOs), Community Based Organisations (CBOs), religious institutions, cultural institutions, foundations, associations, media, academic institutions, interest groups, community groups, youth groups and clubs play a role of ensuring checks and balances in government's exerci-

* Edrine Wanyama is a dual trained lawyer in Uganda and Tanzania. He holds a Master of Laws (LL.M) from the University of Dar es Salaam (Tanzania), a Bachelor of Laws Degree (LL.B) from Makerere University and a Diploma in Legal Practice (Dip L.P) from the Law Development Centre (Uganda). He is an advocate of the Courts of Judicature of the Republic of Uganda (E-mail: edrinewanyama@gmail.com). 
se of its functions. Hence CSOs bring together people with similar interests for social, economic and political reasons.

In Uganda, the history of CSOs dates back to the days of colonialism. Its evolution in Uganda is usually categorized in phases. The first phase is the period between 1920 and 1950 characterized by the elite and working class leadership, cultural and ethnic leadership, welfare and charity centered organisations, as well as the media. ${ }^{1}$ The second phase is that of post-independent Uganda which can also be broken down in phases. Firstly, the phase of the 1970s and 1980, which was more community development oriented. It was nevertheless clamped down by befallen Idi Amin's government which went as far as imposing bans on some organisations such as women organisations in $1973 .{ }^{2}$ Secondly, the phase of 1986 to date under the current ruling government of the National Resistance Movement, then the National Resistance Army provided a friendly environment for CSOs to thrive. As such, there has been steady increase in number of CSOs in Uganda in policy matters, politics, economics and human rights as well as the rule of law. It is for instance on record that in 1986 there were $160 \mathrm{CSOs}^{3}$ By the year 2000 there were 3,500 CSOS. ${ }^{4}$ The progress went on and in 2003 there were 4,700 CSOs. ${ }^{5}$ In 2005 there were 5,500 CSOs and in 2015 there were 12,000 CSOs. $^{6}$ The increase in numbers is attributed to a friendly political operating environment. Steady increase in CSOs has fundamentally impacted service delivery by government through critic and advice through making recommendations as well as drawing government's attention to best practices from other jurisdictions.

Indeed, over the years, CSOs in Uganda have been instrumental in influencing law and policy. Government work, operations and initiatives have hence come into the spotlight over the manner in which governance and the rule of law issues are managed. The state of

1 Richard Ssewakiryanga, "Civil Society in Uganda Systemic Issues for Long Term Development and Sustainability", Kampala, 2015, available at http://ngoforum.or.ug/wp-content/uploads/downloads/2 015/04/DGFAmbassadorsMtg150415.pdf (accessed 31 March 2016).

2 Ssewakiryanga, note 1; see also DENIVA, "Civil Society in Uganda: At the Crossroads?" Kampala 2006. Available at http://www.akdn.org/publications/civil_society_uganda_crossroads.pdf (accessed 31 March 2016) see also Denis Muhangi, "Study of Civil Society Organizations In Uganda", Kampala 2004. Available at http://uphold.jsi.com/Docs/Resources/Research/CivilSociety/civil_society_o rganisation_mapping_study_phase2.pdf (accessed 31 March 2016).

3 Ssewakiryanga, note 1, and Muhangi, note 2.

4 Ssewakiryanga, note 1, and Muhangi, note 2.

5 Ssewakiryanga, note 1, and Muhangi, note 2.

6 Ssewakiryanga, note 1, and Muhangi, note 2. Other reports however estimate that in 2015, the estimated number of registered NGOs in Uganda was 11,000 ("Uganda: NGO bill aims to muzzle civil society, say activists", The Guardian, June 24, 2015) while others give the history of NGOs in Uganda as: From a little less than 200 NGOs in 1986, the official NGO Registry at the Ministry of Internal Affairs shows that by close of 2009, there were 8,385 registered NGOs in Uganda and about 12,500 by the end of 2013 ("A Position Paper and Cause by Clause Analysis of the NGO Bill 2015", a consolidated position on the NGO Bill 2015 under the auspices of the Uganda National NGO Forum), available at http://ngoforum.or.ug/wp-content/uploads/downloads/2015/05/FinalCSO -Position-Paper-on-the-NGO-Bill-2015.pdf (accessed 12 October 2016). 
human rights and the rule of law has been of primary to CSOs, subjecting the government to constant cheques and balances in as far as promotion, respect and protection are concerned. A heavier demand has been put on accountability and transparency of the government to its constitutional duties and obligations. Accountability has nevertheless attracted sharp criticism against the government by civil society. To government, criticism is often not welcome. It is now associated with the opposing forces to the current legitimate government. Growth of CSOs in Uganda has not only put pressure on the government to account for its decisions but also attracted increasing intolerance for CSO work for reasons that CSOs have become more of critics of government and rarely acknowledge achievements of the government. The result is the narrowing space of operation for CSOs.

\section{B. Categories of Civil Society Organisations in Uganda}

Civil Society Originations find meaning from the Non-Governmental Organisations Act, 2016. Accordingly, section 3 defines what qualifies to be an organisation that is regulated by the Non-Governmental Organisations Act, 2016. An organisation according to this law refers to legally constituted non-governmental organisations, which may be private voluntary grouping of individuals or associations established to provide voluntary services to the community or any part, but not for profit or commercial purposes. Further, the different definitions of different kinds of CSOs under the section 3 of the law include:

(i) Community Based Organisations, which mean organisations operating at a sub-county level and below, whose objectives is to promote and advance the well-being of the members of the community.

(ii) Continental organisations, which mean organisations that have their original incorporation in any African country, other than the Partner States of the East African Community, and are partially or wholly controlled by citizens of one or more African countries, other than the citizens of the Partner State of the East African Community, and are operating in Uganda Under the authority of a permit issued by the Bureau.

(iii) Foreign organisations, which mean organisations that do not have original incorporation in any country, and are partially or wholly controlled by citizens of other countries, other than the citizens of the Partner States of the East African Community, and are operating in Uganda under the authority of a permit issued by the Bureau.

(iv) Indigenous organisations, which mean organisations that are wholly controlled by Ugandan citizens.

(v) International organisations, which mean organisations that have their original incorporation in a country, other than a Partner State of the East African Community and are partially or wholly controlled by citizens of one or more countries, other than the citizens of the Partner States of the East African Community, and are operating in Uganda under the authority of a permit issued by the Bureau.

(vi) Regional organisations which mean organisations incorporated in one or more of the Partner States of the East African Community, and which are partially or wholly con- 
trolled by citizens of one or more of the Partner States of the East African Community, and which are operating in Uganda under the authority of a permit issued by the $\mathrm{Bu}-$ reau.

Within the above definitions are purely non-governmental organisations. It is important to note that civil society is comprised of diversity of organisations as indicated above. It is further important to note that while other organisations like media and telecommunications, political and other profit oriented or commercial organisations are categorized as civil society, they are governed by legislation that purely provide for the manner of their registration and activities as well as their scope of operation. For instance, political organisations are governed by the Political Parties Organisations Act, 2005 while the media is governed by the Uganda Communications Act, 2013, Press and Journalist Act, Cap 105. Some of them, especially the media and telecommunications, are as much affected as NGOs while some of the commercial initiatives do not face very hard challenges in as far as the operating environment is concerned.

\section{Legal Framework Governing Civil Society Organisations}

The Constitution of the Republic of Uganda, 1995 (Uganda Constitution), does not have a particular article that seeks to protect and promote the work of CSOs in Uganda. Nevertheless, directive V (ii) of the Constitution requires the State to guarantee and respect the independence of non-governmental organisations which protect and promote human rights. ${ }^{7}$ Additionally, NGOs are free to found and operate educational institutions if they comply with the general educational policy of the country and maintain national standards. ${ }^{8}$ Equally, CSOs are included in the definition of any person or organisation who or which may apply to a competent court for redress which may include compensation for violation of another person's or group's human rights. ${ }^{9}$

From the reading of the Constitution, the makers of the Constitution were cognisant of Uganda's history and, therefore, created a favourable environment for establishment and survival of CSOs. In the wake of an open and friendly environment, CSOs have taken advantage and increased their demands on the government in the name of promoting interests of the citizenry. A favourable environment for civil society operations has over the years led to negative criticism of the government even where it has performed fairly or exceptionally well. It has accordingly got to be commonly known that CSOs hardly acknowledge government efforts in transforming society. As a measure by the State, government has be-

7 Constitution of the Republic of Uganda, 1995, directive V (ii) of the National Objectives and Directive Principles of State Policy.

8 Uganda Constitution, note 7, directive XVII (iii).

9 This provision has been validated by the decision in Greenwatch (U) Limited v Attorney General and Uganda Electricity Transmission Company Ltd, High Court Ruling No. 139/2001 in which Court held that "...corporate bodies can enforce rights under the bill of rights for they are taken as persons in law, though not natural persons.". 
en forced to devise means of limiting and regulating civil society activities. Indeed, the change in legal regime is partly reasoned on subversive methods of work and activities, which in turn undermine accountability and transparency in civil society sector. ${ }^{10}$ As a control measure, legislation with serious implications on CSOs' work has been passed. For instance, in the past decade, a number of laws which directly affect civil society space have been passed. Some of the laws deliberately prescribe strict regulation measures and restrict activities of CSOs while other threat CSOs with closure where they are non-compliant. ${ }^{11}$ Legislation from historical construction and the current time thus goes to the core of the operations of CSOs.

\section{State of Civil Society Organisations}

The current state of CSOs is two-fold. The first arises from external factors including the government or State control forces and reliance on donor funding which in turn determine the scope of operation. The second arises from internal factors, which mainly includes issues associated with self-governance. In light of the above, discussions under this section will be categorised in external and internal factors. It is important to note that the factors of an internal and external nature have often dictated the environment in which CSOs currently operate.

\section{External Factors}

\section{Civil Society Perceived as Partisan}

Civil society is now of very high interest to State investigations for they are now politically critical of the government. With current political developments in Uganda there have been and are likely to be direct and indirect attacks on CSOs with a pose of a great risk of closure. This situation and risk of CSOs has further been shown the just completed presidential petition in which CSO's application for amicus curie on 10 March 2016. The CSOs were performing part of their mandate of ensuring protection of constitutionalism, human rights and democracy as a way of ensuring rule of law and accountability in government. The

10 Alon Mwesigwa, "Uganda: NGO bill aims to muzzle civil society, say activists", The Guardian, June 24, 2015, available at https://www.theguardian.com/global-development/2015/jun/24/uganda -ngo-bill-aims-muzzle-civil-society-say-activists (accessed 12 October 2016).

11 The legal framework governing CSOs' operations in Uganda include the: Constitution of the Republic of Uganda, 1995 as amended, 2006; Non-Governmental Organizations Act, 2016; Anti-Terrorism Act, 2002 as amended 2015; Public Order Management Act, 2013; Police Act Chapter 303 as amended 2006; Anti-Homosexuality Act, 2014; Income Tax Act Chapter 340; Value Added Tax Act; National Social Security Fund Act Chapter 222; Trustees Act, Chapter 164; trustees Incorporation Act, Chapter 165; Anti-Money Laundering Act, 2013; Public Finance Management Act, Act. No. 3 of 2015; Pensions Act, Chapter 286; East African Community Customs Management (EACC) Act (2004); and the Non-Governmental Organisations registration Regulations, 2009 among others. 
CSOs' application was rejected on grounds that they did not have the required competence and that adding them to the petition would be prejudicial. ${ }^{12}$ They were also branded partial in the process. In the circumstances, the future of CSOs still remains uncertain and one cannot rule out political threats. Indeed some reports say that the new Non-Governmental Organisations Act, 2016 was assented to after CSOs filed an application for amicus curie though it was back dated to read 30 January 2016. ${ }^{13}$ The Non-Governmental Organisations Act, 2016, imposes wide duties and obligations in compliance and operations across the country. It makes CSO operations more of requiring political authorisation than meeting peoples' social needs. When the current political space and work of CSOs is evaluated, the conclusion is that CSOs are now highly identified with the opposing forces to the legitimate government.

The debate nevertheless surround the question, whether CSOs are playing an impartial role, facilitated fair evaluation of government's state of service delivery or are purely grounded on negative criticism. For instance, the government has a primary mandate of protecting its citizens under international and domestic legislation. Government usually carries out consultation with the citizens. On the other hand, CSOs are usually fast to conclude that the government does not effectively conduct public consultations. Further, CSOs have tended to side with the opposing political forces of government than with the ruling government. It is also important to note that CSOs' workers have individual sentiments on the state of governance of Uganda, these sentiments are later presented as views of CSOs and yet they may be individually motivated. There is no option but for the State to adopt measures that can effectively limit activities of CSOs.

Summarily, narrowing space of operation for CSOs is attributed to individual sentiments expressed by individuals who are part of the wider civil society as well as increased fear by the State for the criticism of CSOs over its activities. In the current democracies it is quite hard that CSOs, especially now that they have politically motivated employees and authoritatively engage the public, are left to operate as they wish. This partly accounts for the current narrowing space in Uganda because government has limit CSO activities for they are regarded as engaging in subversive activities. ${ }^{14}$

12 Anthony Wesaka, Ivan Okuda, Isaac Imaka and Othman Semakula, "Supreme Court Allows Makerere Law Dons to Join Amama Petition, Rejects CSOs”. The Monitor Monday, 14 March 2016. Available at http://www.monitor.co.ug/News/National/Supreme-Court-allows-Makerere-law-donAmama-petition/-/688334/3116294/-/dlawogz/-/index.html (accessed 1 April 2016).

13 Library of Congress, Global Legal Monitor, "Uganda: Non-Governmental Organizations Bill Becomes Law". Available at http://www.loc.gov/law/foreign-news/article/uganda-non-governmentalorganizations-bill-becomes-law/ (accessed 1 April 2016). See also Amy Fallon, "Repressive NGO Act”, Inter Press Service News Agency. Available at http://www.ipsnews.net/2016/03/repressive-n go-act/ (accessed 1 April 2016).

14 Mwesigwa, note 8. 


\section{Legal Environment}

In the past years legal means have been used to try and stifle civil society work. Strategy is usually investigations into legal compliance and initiating and passing of draconian legislation. Some of the legislation targeted includes the Non-Governmental Organisations Act, 2016, revenue and taxation laws as well as social security laws. Today the scope is even wider especially with laws supposedly drafted with ambiguities such as the Public Order Management Act (POMA), the Anti-Terrorism Act and public finance laws.

\section{a) The Non-Governmental Organisations Act, 2016}

The Non-Governmental Organisations Act, 2016 (NGO Act) in the opening sentences of the long title sounds progressive in as far as it states inter alia that it is a law to provide for; a conducive and enabling environment for the NGOs sector; strengthening and promotion of the capacity of NGOs and their mutual partnership with government; making provision for the corporate status of the National Bureau for Non-Governmental Organisations and provides for the capacity of the National Bureau to register and regulate the operations of CSOs. Hence, all organisations intending to operate in Uganda as CSOs must ensure that they register with the bureau and must, in their operations ensure that they work within the goals and objectives approved by the Bureau. Failure to adhere to the adhere to the spelt functions may lead to revocation of a permit as provided in section 33 of the NGO Act or the person or organisation being charged with an offence which may attract a fine of Uganda Shillings 1,400,000 (US-\$390) or imprisonment for a period not than three years or both as spelt out under section 40 of the NGO Act. Nevertheless, the law establishes the board of directors and allows for formation of sub-committees by the board, district and sub-county Non-Governmental Organisations Monitoring Committees. The above committees are not meant for anything else but for stifling the work for CSOs such that CSOs cannot do any activity in any given area unless there is a common understanding. ${ }^{15} \mathrm{It}$ is further intended to create bureaucratic process that would not only delay but also frustrate the work of CSOs. Further effect is that in light of section 44 of the Act CSOs can no longer have direct access to the people. They must rather ensure that local councils and the different monitoring committees are aware of their activities. Moreover the local authorities and committees may refuse to grant them permission to meet the people.

Likewise the NGO Act under section 30 (1) (a) demands that an organisation shall not be registered under the Act where the objectives of the organisation as specified in its constitution are in contravention of the laws of Uganda. This implies that while the law is pro-

15 See for instance section 44 (a) of the NGO Act. It bars any CSO from carrying out any activity in any part of the country, unless it has received the approval of the DNMC and Local Government of that area and has signed a memorandum of understanding with the Local Government to that effect. Section 44 (b) further bars CSOs from extending their operations to any new area beyond the area it is permitted to operate unless it has received a recommendation from the Bureau through the District and Sub-county Non-Governmental Organisations Monitoring Committee of that area. 
gressively justified for legal compliance. Indeed the current development in the country reveals that some organisations such as those working on gay and lesbian rights will not be registered under the section. ${ }^{16}$ It is important to observe that CSOs under the new law are subjected to a more tiring and burdensome procedural process before registration. They must accordingly get recommendations from local councils which a three in number, the Resident District Commission, a line Ministry and other government representatives. Worse still, the law empowers the National Bureau for NGOs to register NGOs. This means that registration of NGOs may be at the whims of the Bureau.

Further, section 44 (d) and (f) in as far as they provide that an organisation shall not engage in any act which; is prejudicial to the security and laws of Uganda and prejudicial to the interests of Uganda and the dignity of the people of Uganda respectively. In the first place the two provisions are vague in definition and do not define what is prejudicial. Secondly, security reasons have been used in the recent past to limit enjoyment of the right to information, freedom of speech and expression and assembly and demonstration. ${ }^{17}$ There is accordingly no doubt that these provisions are going to be used for furtherance of continued clamp down of CSOs' work. It is noteworthy at this level to state that the usage of vague terms is not only unconstitutional and contrary to article 28 (12) of the Uganda Constitution that requires for clear definition of criminal offences, but a means to limiting and frustrating the practice and enjoyment of human rights and freedoms in Uganda.

Despite the above analysis, it is imperative that one looks beyond legislation and the vagueness it may contain. Owing to the fact that the new NGO law has wide requirements as well as restrictions, there is no doubt that they were triggered by the current CSOs activities. For instance same sex marriages and sexual practices regarded as against the order of nature are still illegal in Uganda. ${ }^{18}$ CSOs have, however, in the recent times been actively

16 Human Rights Awareness and Promotion Forum, "Position Paper on the Non-Governmental Organisations Act, 2016", 2016. Human Rights Awareness and Promotion Forum, 2016. Available at http://hrapf.org/?mdocs-file=1669\&mdocs-url=false (accessed 19 September 2016).

17 Human Rights Awareness and Promotion Forum, note 16.

18 Uganda Constitution, note 7, article 31 (1) provides inter alia, A man and a woman are entitled to marry only if they are each of the age of eighteen years and above and are entitled at that age - (a) to found a family; and

(b) to equal rights at and in marriage, during marriage and at its dissolution. Further 31 (2a) is to the effect that marriage between persons of the same sex is prohibited. The article is very instructive and on marriages, it refers to "a man and woman". Further, section 145 of the Penal Code Act Chapter 120 criminalizes carnal knowledge against the order of nature, carnal knowledge of an animal or carnal knowledge of a man or woman against the order of nature. It is important to note here that even mere attempt to commit unnatural offences under section 145 of the Act amounts to a felony. Further, assault with intent to have carnal knowledge of any person against the order of nature, or an unlawful and indecent assault upon a male person is criminalized by section 291 (1) (f) of the Act. 
engaged in advocacy around gay rights. ${ }^{19}$ The active involvement and advocacy initiatives in gay and lesbian rights partly led to the need for regulation by the State and hence the introduction of the Anti-Homosexuality Bill, 2009, the Prohibition of Promotion of Unnatural Sexual Practices Bill, 2014 which later was named the Sexual Offences Bill, 2015. The triggers for control by the State perhaps lie in the State's view of gay and lesbian rights as a conspiracy by the Western States and, therefore, the need to protect a common public good, including morals, traditions, customs and culture. ${ }^{20}$ Likewise, CSOs were getting funding towards advocacy and promotion of rights that the State still considers against the moral values of its citizens. ${ }^{21}$ The State thus has to put in place preventive measures, which usually manifest in introduction of new legislation. It is now quite obvious that the introduction of requirement of CSOs to provide memoranda of understanding between them and donors, sponsors and foreign partners is a control and preventive measure by the State of the infiltration of some agendas into Uganda's citizenry. This has for instance come out clearly in Human Rights Network and Seven Others $v$ The Attorney General Constitutional Petition No. 5 of 2009 in which the court has categorically stated that

"The necessity of registration is to enable Government to assess the objectives of the $N G O s$ and to ascertain whether the activities that are intended to be carried out are lawful. It is also important to monitor and ensure that NGOs do what they set out to do in the geographical areas of their registration. In short, the monitor and ensure that the regulation is merely to operationalize, objectives of Civil Society Organisations are not contrary to the Constitution and to protect the NGOs in their lawful activities. ${ }^{22}$

19 For instance, in 2012, Uganda is reported to have imposed a ban on 38 organisations accused of promoting homosexuality. See also David Smith, "Uganda bans 38 organisations accused of 'promoting homosexuality"', the Guardian, June 20, 2012, available at https://www.theguardian.com/w orld/2012/jun/20/uganda-bans-organisations-promoting-homosexuality (accessed 13 October 2016).

20 Maria Burnett, "Uganda making life tough for NGOs, LGBT rights." Human Rights Watch, 30 August 2012, available at https://www.hrw.org/news/2012/08/30/uganda-making-life-tough-ngos-1 gbt-rights (accessed 13 October 2016).

21 Huff Post, "The Ugandan Gay Rights Crisis and the Hypocrisy of the West", available at http://ww w.huffingtonpost.co.uk/liam-deacon/uganda-gay-rights_b_4973915.html (accessed 13 October 2016).

22 In this case, the petitioners filed the case in the Constitutional Court for interpretation. They alleged that Sections 2 (1), 8 (a), (b) and, (c), of the NGO Act (now over taken by events through the enactment of a new law to govern and regulate NGOs) and Regulations 5,7,8,13,17 respectively contravene Article 29 (1) (C) and (e) of the Constitution. They further alleged that said sections of the NGO Act and Regulations are contrary to Article 22 of the International Covenant on Civic and Political Rights (ICCPR) and the East African Community Treaty. The petitioners submitted that the new law had the effect of restricting operations of CSOs contrary to the constitution and that it would be used by government to impose burdens on CSOs. The respondents argued otherwise and asked that the petition be dismissed. On the $4^{\text {th }}$ February 2016 , seven years after petition was filed, the justice of the Constitutional Court held that petitioners did not show that the im- 
And of course, the State has to take every measure with the aim of guarding its interests and the interests of the people. It is very obvious that the State has to take charge over the operations of the private sector for a primary reason of ensuring that there are no parallel activities oppose to the agenda of the government in power.

\section{b) The Public Order Management Act, 2013}

The Public Order Management Act, 2013 (POMA) provides for the regulation of public meetings, the duties and responsibilities of the police, organisers and participants in relation to public meetings and prescribes measures for safeguarding public order. The POMA however raised concerns in the public domain including section 3 which gives extensive powers to the Inspector General of Police (IGP) or authorised officer to regulate assemblies of CSOs. This means that the IGP has the final answer to as to whether a public assembly should be held or not. Further section 4 (1) vaguely defines a public meeting as gathering, assembly, procession or demonstration in a public place or premises held for the purposes of discussing, acting upon, petitioning or expressing views on a matter of public interest. Further, section 4 (3), a meeting held by group, body or leader in a group or body in its ordinary place of business or other place, not a public place may become a public meeting when it spills over into a public place. To further restrict assemblies, sections (5), 6(1) and (3), 7(2), 8, 9, 10, 12, 13 restrict meetings. The effect is limitation on the exercise fundamental rights and freedoms. The police is accordingly broadly authorised to use force to disperse assemblies, arrest, charge and impose criminal responsibilities on organizers and participants of public meetings. Such restrictions are obviously contrary to Objective XXVIII of the National Objectives and Directive Principles of State Policy and articles 2(2), 21(1), 21(2), and 21(3) 29(1) (a), 29(1) (d), 29(1) (e), 30, 38(1), 38(2) and international legal human rights standards. ${ }^{23}$

It is further important to note that the POMA was also passed in disregard to constant calls by CSOs to remove sections 5 and 6 which were similar to section 32 (2) of the Police Act which was outlawed by the decision in Muwanga Kivumbi v. Attorney General Consti-

pugned Sections and Regulations infringe on enjoyment of human rights and freedoms and that the laws was intended to offer protection of the public and public interest and therefore dismissed the petition. This judgment has been viewed bad and approached with criticism by CSOs for delays in passing judgment, and after presidential assent (January 30, 2016) to a new law (Non-Governmental Organisations Act, 2016) that replaced the law that was still being challenged in Court. It is regarded by some activists, a mockery of the justice systems.

23 Objective XXVIII provides for foreign Policy Objectives including the respect for international law and treaty obligations. Article 2 provides for supremacy of the Constitution over all authorities, laws and persons. Article 21 provides for equality and freedom from discrimination. Article 29 is on the Protection of freedom of conscience, expression, movement, religion, assembly and association. Article 30 is on the right to education of all persons. Article 38 provides for the right to participate in civic rights and activities. 
tutional Petition No. 9/05. ${ }^{24}$ The enactment of sections 5 and 6 was a contravention of article 92 of the Constitution. ${ }^{25}$

In terms of evaluation, the POMA was partly a strategy for controlling civil society activities which may be considered subversive to the government. It is quite obvious that CSOs usually discuss matters of public interest that may cause sabotage and rebellion against the government. Consequently, there has been a shift of CSOs from complementing the role of the government in service delivery to advocacy. ${ }^{26}$ Advocacy is usually aimed at causing change in existing situations. The State has, therefore, increasingly become sceptical of the manner in which CSOs do their work and hence the need to seriously regulate their activities within the law. They are allowed to continuously interact with the public, there must be a level of control by the government to ensure that it does not face serious potential resistance from the public that could easily result to its downfall or overthrow. Though control measures are necessary for the State, it is important to note that there has been a tendency towards regression by the State as reflected by the above analysis with a deliberate effort to restrictively regulate enjoyment of civic rights in Uganda.

\section{c) The Anti-Terrorism Act, 2002 as Amended 2015}

Terrorism is now a major global threat. Uganda has not been spared and the genesis of terrorism dates back to the Lord's Resistance Army which operated in Northern Uganda since $1988,{ }^{27}$ the Allied Democratic Front which started in 1997 and the climax was the 2010 twin suicide bombings during a FIFA World Cup final leading to the death of 76 people. ${ }^{28}$ There have also been attacks in different parts of the especially the western part of the

24 The passing of section 8 was a reintroduction of section 32 (2) of the Police Act, Chapter 303. This was a violation of article 92 of the Uganda Constitution which bars the Parliament from legislating on a matter court has held otherwise. Section 32 (2) of the Police Act, Chapter 303, gave powers to the IGP to stop or prohibit the holding of a public assembly.

25 Article 92 provides that Parliament shall not pass any law to alter the decision or judgment of any court as between the parties to the decision or judgment.

26 See for instance David Devlin-Foltz, "Civil Society Advocacy in Uganda: Lessons Learned", available at https://assets.aspeninstitute.org/content/uploads/files/content/docs/pubs/Civil_Society_ Advocacy_in_Uganda.pdf (accessed 21 October 2016); Abigail Barr, Marcel Fafchamps, and Trudy Owens, "Non-Governmental Organisations in Uganda: A report to the Government of Uganda", available at http://sarpn.org/documents/d0000716/NGO_Uganda_Dec2003.pdf (accessed 21 October 2016).

27 ALJAZEERA, "Profile: The Lord's Resistance Army, May 6, 2014”, available at http://www.aljaz eera.com/news/africa/2011/10/2011101418364196576.html_(accessed 21 October 2016).

28 ALJAZEERA, "Uganda foils 'terrorist' attack", 13 September 2014, available at http://www.aljaze era.com/news/africa/2014/09/uganda-foils-terrorist-attack-201491312302715418.html (accessed 21 October 2016). 
country in the district of Kasese. ${ }^{29}$ Uganda has consequently joined the rest of the world in adopting counter-terrorism measures. The measures are both legal and administrative.

As part of legal measures, Uganda passed the Anti-Terrorism Act, 2002 to suppress acts of terrorism, to provide for the punishment of persons who plan, instigate, support, finance or execute acts of terrorism; to prescribe terrorist organisations and to provide for the punishment of persons who are members of, or who profess in public to be members of, or who convene or attend meetings of, or who support or finance or facilitate the activities of terrorist organisations; to provide for investigation of acts of terrorism and obtaining information in respect of such acts including the authorising of the interception of the correspondence of and the surveillance of persons suspected to be planning or to be involved in acts of terrorism. ${ }^{30}$

It is quite obvious that the anti-terrorism law was good intentioned and aimed at preventing all acts of terrorism. Preventive measures are necessary for there is no assurance that all CSOs are not motivated by other intentions like terrorism. However, under section 7 (2) (k) the law makes provision for the acts of terrorism where inter alia, one for purposes of influencing the government or international government for a political, religious, social or economic aim, indiscriminately without due regard to the safety of others or property and if death results as a result of intended violence, an act of terrorism arises. The issue here is that while the provision is clear, it is not cognisant of the fact that death of an individual may be politically motivated. Hence exercise of rights by CSOs' activists such as assembly and demonstration may amount to acts of terrorism if death of an individual occurs as a result of an assembly or public demonstration. This means that CSOs cannot exercise civic rights without permission from police. Getting the said permission is also subjective and may not be granted.

\section{d) The Anti-Pornography Act, 2014}

Under the Anti-Pornography Act, section 17, internet service providers commit offences if a user of their service downloads or uploads pornography may be heavily penalised or imprisoned for a period not exceeding five years or both. Further, under section 19 a director or secretary of a body corporate or a partner in a firm proved to have contributed to access to pornographic materials is deemed to have committed an offence. Consequently, the government is primarily interested in protecting public morals and children as well as women against acts of pornography. It is also possible that the law was informed by emerging acts of what the government regards as immoral including gay rights, bestiality and all acts of sex against the order of nature. Nevertheless, corporate bodies and firms form part of civil society. It follows that above provisions are disregard of the fact that civil society organisa-

29 F. WORLD, "Uganda: 93 people killed in tribal attacks, say police", available at http://www.firstp ost.com/world/uganda-93-people-killed-tribal-attacks-say-police-1617647.html (accessed 21 October 2016).

30 Anti-terrorism Act, 2002, long title. 
tions have individuals from all walks of rights and may not therefore be monitored or effectively controlled. Additionally directors and partners of corporate bodies and firms respectively are usually the top leadership. To hold them liable for offences they did not commit is to cripple the function of the institution that may be affected. It also poses questions as to why one would be held liable for criminal acts of another. It is nevertheless important to note that the State is obligated to protect its citizens from what it considers unlawful. In this case, a counter argument to the implications of the anti-pornography law on CSOs is that the government finds protecting its citizens against pornography its sole responsibility and therefore legislation against pornography, which ideally forms part of freedom of information and freedom of expression rights.

\section{e) The Anti-Money Laundering Act, 2014}

Under the Second Schedule to the Anti-Money Laundering Act, paragraph 15, non-governmental organisations, churches and other charitable organisations which form part of civil society are listed as forming part of accountable bodies. Under section 7 of the Act an accountable person is inter alia required to establish and maintain information obtained about the true identity of the person on whose behalf a business relationship is initiated or a transaction is conducted for at least ten years and a readily recoverable form of the said information for a similar period. The section further requires for establishment and maintenance of records for establishment and reconstruction of transactions required to be reported under the Act, for at least ten years after the conclusion of the transaction. Indeed accountable persons are required to report and take record of every transaction exceeding one thousand currency points (about US-\$ 6,061). ${ }^{31}$ The period of ten years is too long and makes it highly possible that all records will not be kept in good shape for the period. Additionally, there are so many demands on disclosures and maintenance of records on CSOs which widely clamps down on the work of CSOs. Records keeping and reporting obligations also affect CSOs owing to the fact that CSOs primarily depend on donor funding. They may be found to be non-compliant not because they deliberately do so but because of other factors such as loss of records as well as misplacement.

From the select legal framework, it is quite clear that legislation is passed with regressive provisions with the aim of limiting operations of CSOs. It is one way of narrowing the space of CSOs operations in Uganda. Narrowing the space of operation has a direct impact on the practice and exercise of democratic and human rights, because it trims the critical role of CSOs in holding governments accountable for its actions. It is also an avenue for which government can regress into secrecy amidst absence of criticisms from CSOs in fear of facing closure and persecution.

Despite the narrowing space of financial requirements, government does not fully trust CSOs activities as well as their sources of funds. Distrust arises from the huge sums of mo-

31 Anti-Money Laundering Act, 2014, section 8. 
nies that NGOs sometimes have, that may facilitate jeopardizing the governance of the country. For instance, in the recent past, some NGOs have been accused of supporting opposition parties to oust the government while others have been accused of conniving with foreigners to criticize and blackmail the government. Some of the CSOs accused include the Advocates Coalition on Development and Environment (ACODE) which was slammed by President Yoweri Museveni that ACODE had spent over 1.5 billion Ugandan Shillings (US-\$ 436,140) on a single retreat of legislators at the peak of the Petroleum (Exploration, Development and Production) Bill on the allegation that it was misleading MPs and working as an agent of foreign interests. ${ }^{32}$ Information that followed investigation showed that the money spent was a quarter of the alleged total sum. ${ }^{33}$ Nevertheless, irrespective of the discoveries, it became imperative on government to regulate financial flows into the country. The allegations of spending money on the ministers and members of parliament had also posed questions as to the intended purpose. ${ }^{34}$ Government has in that respect adopted legislative measures to manage CSOs and any would be cases of illicit activities such as funding of the opposition as well as unrest or uprising against government. ${ }^{35}$ It is obviously expected that government has to be concerned with individuals and CSOs which huge sums of money and would also be interested in disclosure of the sources. Nevertheless, it does not guarantee clamp down on the activities. Working together and openly would provide solutions and remove suspicions on CSOs of possible engagements in subversive activities against government. ${ }^{36}$

\section{Security and Safety}

It is crucial to look into physical protection employees of CSOs as well as the physical structures within which CSOs operate. The Uganda Police Force is charged with the protection of lives and property of citizens.

There has been persecution of CSOs' staff through arrests and detention without clear reason. Arrest and detention has often killed the morale of CSOs staff to engage in in proactive democracy and human rights in fear of persecution. ${ }^{37}$ Equally, a number of organisations have been broken into and lives, vital documents, information, money and property we-

32 Chimp Reports, "ACODE's Untold Struggle for Democracy and Good Governance in Uganda", 25 January 2013, available at http://www.chimpreports.com/7890-acodes-untold-struggle-for-democr acy-and-good-governance-in-uganda/ (accessed 13 October 2016).

33 Chimp Reports, note 32.

34 Chimp Reports, note, 32.

35 Chimp Reports, note, 32 .

36 Chimp Reports, note 32, Godbar Tumushabe, then Executive Director of ACODE, reveals the extent of partnership with the ruling government as well as the opposition in its objective of the struggle for democracy and good governance in Uganda. He also reveals the achievements of ACODE as an NGO in Democratic processes and security enhancement of Uganda.

37 Human Rights Watch, "World Report 2015: Uganda Events of 2014". Available at https://www.hr w.org/world-report/2015/country-chapters/uganda (accessed 19 September 2016). See also AWID, 
re lost. Office structures have also been damaged as a result of break-ins. The developments of target nthreats on CSOs have resultantly crippled the work of CSOs. Presently, over fourteen CSOs have been broken into including the ZOA (Dutch translation of South East Asia) Refugee Care, the Human Rights Awareness and Promotion Forum (HRAPF), the Forum for African Women Educationalists (FAWE), the Land and Equity Movement in Uganda (LEMU), the Uganda Road Sector Support Initiative, the Women and Girl Child Development Organisation, the Anti-Corruption Coalition (ACCU), the Foundation for Human Rights Initiative (FHRI), the Environmental Alert, the Human Rights Network Uganda (HURINET), the Action Aid International Uganda, the Uganda Land Alliance (ULA), the Human Rights Network for Journalists (HRNJ), the Teso Initiative for Peace (TIP), the Action Group for Health Human Rights \& HIV/AIDS (AGHA Uganda), the Summit Foundation (SUFO) and the Lira NGO Forum and Access Initiative, among others. ${ }^{38}$ The attacks on CSOs form a series of failed police accountability on investigations. There has indeed been no successful investigation on any of the above cases. Even where there has been leading evidence such as the recordings of CCTV cameras, nothing has yielded. In the circumstances, there is no concrete information to inform the objects of constant break-ins and impunity continues hovering all-over. The activities of the unknown criminal gangs have heavily affected operations of CSOs. Constant fear is for the safety and security of staff as well as assets and information of CSOs.

\section{Reliance on Donor Funding}

There is no clear internal income generation initiative in Uganda for CSOs. Civil society purely depends on donor funding. The problem of foreign donor dependency has been worsened by the basket funding strategy by donors. Donor reliance becomes a major problem when applications are made for financial resources and no approvals are made for funding. CSOs that do not get any approval for funding have no option but to close. In the past, when basket funding was not in existence, the chances for CSOs to get funding were diverse and hopes were equally high. With the new breed of basket funding, it is increasingly hard for CSOs to get funding. Even where there would be hope for internal income generation, Ugandan population is poor that that there would be no sustainable support towards

\footnotetext{
"Women Human Rights Defenders in Uganda Face Unlawful Criminalization", Protection online, 2012. Available at http://protectionline.org/2012/08/19/women-human-rights-defenders-in-ugandaface-unlawful-criminalization/ (accessed 19 September 2016); Health Gap, "Ugandan Police Attack LGBT Pride Event: Arrests, Beatings, Assaults on Participants", 2016 available at http://w ww.healthgap.org/activists_condemn_ugandan_police_attack_on_pride_celebration (accessed 19 September 2016).

38 Frontline Defenders, "Uganda - Break-in and theft at offices of the Human Rights Awareness and Promotion Forum", 2016. Av<liable at https://www.frontlinedefenders.org/en/file/2393/download? token=BBHPdRTa (accessed 19 September 2016). See also Human Rights Watch "Uganda: Investigate Break-ins at Groups' Offices”, 2016 available at https://www.hrw.org/news/2016/06/13/uga nda-investigate-break-ins-groups-offices (accessed 19 September 2016).
} 
CSOs' activities and their work and survival. The dilemma with funding raises questions of accountability of CSOs for donor funds. Perhaps CSOs have not been transparent enough to warrantee continued financial support. Likewise, the problem may be facilitated by the global economic shrink and the current mass migrations into major world economies, that there cannot be assured constant funding.

\section{Ignorance of the Public Due to Information Gaps}

The public primarily forms the civil society. However, Uganda's public falls short of knowledge on the operations of human rights and democracy and rule of law initiatives. Accountability and transparency has therefore continually become a problem in Uganda both on the part of government and the public. While the public lacks knowledge on human rights and CSOs' operations, government has hardly done enough to sensitize the citizenry on laws and how they operate. In ignorance of existing initiatives, CSOs' operations have not yielded much. The people are partly not cognisant of CSOs' roles in service delivery and their complementing role to the State in as far as bringing services closer to the people is concerned. This has not only led to a passive population but also made the work of CSOs to some sections of the public. Accountability has accordingly not attained full meaning in the available civic space.

\section{E. Internal Factors}

\section{Non Compliance with Legal Requirements}

Despite the fact, that archaic and draconian legislation continues to affect CSOs, these organisations have to some extent failed to cope with legal compliance. Ideally, primary effort should be dedicated towards ensuring continued survival amidst the shrinking space. CSOs have, nevertheless, failed to comply. In 2013, Human Rights Network Uganda (HURINETU) conducted a Member Organisations Capacity Assessment. In the report findings it was revealed that some legally registered organisations struggle to be fully compliant with the relevant laws. ${ }^{39}$ Further, unregistered organisations were unfamiliar with the relevant laws. ${ }^{40}$ The report further observes that risk management in the network is very poor with only seldom trained staff in the area of risk management. ${ }^{41}$ Non-compliance is attributed to the historical developments of the civil society in Uganda. The shift from dictatorship regimes created a favourable environment for CSOs' development and progress. The current regime was also compliant with the Uganda constitution and was social development centered. CSOs thus became reluctant as the State and State agencies were equally not vigilant in

39 Human Rights Network Uganda, "Member Organizations Capacity Assessment Report”, Kampala 2013. Available at https://www.hurinet.or.ug/?wpfb_dl=1408 (accessed 1 April 2016).

40 Human Rights Network Uganda, note 39.

41 Human Rights Network Uganda, note 39. 
ensuring legal compliance by CSOs. In the wake of an upper arm of government to control, limit and restrain some actions of CSOs, every fault is being identified to clamp down CSOs' work.

It is important to note that the HURINET-U capacity assessment report observes that majority CSOs are compliant with the law in Uganda. ${ }^{42}$ Nevertheless, effects of non-compliance are likely to spill to the legally compliant. The State and security agencies are most likely to brand all organisations as violators of the law. Equally, with the narrowing aid and donor funding for the government, majorly arising from direct cuts and finding preference in CSOs for trust of delivery has impacted on governments reaction towards CSOs. In the wake of tight government control, CSOs have limited options for survival. The main and key option to ensure survival is compliance with the law. Where a CSO is found to be noncompliant with the law, the chance of its surviving is very minimal.

\section{Internal Governance}

Non-governmental organisations in Uganda have developed a self-assessment initiative, Quality Assurance Mechanism (QuAM) ${ }^{43}$ The QuAM is aimed at enhancing the credibility and effectiveness of NGOs and contributing to the overall improvement in the public legitimacy of the civil society sector. ${ }^{44}$ The QuAM is also aimed at setting a credible NGO sector for the promotion of good governance and improvement of service delivery in the country. ${ }^{45}$ It is quite obvious that the QuAM is aimed at promoting the adherence by Civil Society Organisations to generally acceptable ethical standards and operational norms. ${ }^{46}$ The QuAM also sets out principles and standards of behaviour for responsible practice, to protect the credibility and integrity of certified NGOs and their networks in Uganda. ${ }^{47}$ The reasons advanced for QuAM are eight in number and it is believed that an organisation with a QuAM certificate will enhance its credibility, legitimacy, protection and autonomy performance, accountability, profile as well as learning from examples. ${ }^{48}$

Despite the above effort and mechanism, CSOs have not had a smooth sail through accountability from the government, citizens and donors. They are seen as corrupt in both financial management and human resources recruitment and retention. Indeed, some individuals have stated that civil society does not even have the moral authority to challenge go-

42 Human Rights Network Uganda, note 39.

43 QuAM, "What is QuAM?" available at http://www.quamuganda.org/about-quam/what-is-quam (accessed 1 April 2016).

44 QuAM, note 43.

45 QuAM, note 43.

46 QuAM, “About QuAM", available at http://www.quamuganda.org/about-quam (accessed 1 April 2016).

47 QuAM, note 46.

48 QuAM, “WHY QuAM?”, available at http://www.quamuganda.org/about-quam/why-quam (accessed 1 April 2016). 
vernment on the existing trends of corruption for they are equally corrupt. For instance, in 2014, it was reported that, “... Mr Arthur Larok, the country director, Action Aid International Uganda, a key founder of the anti-corruption drive, Black Monday Movement was thrust in the limelight over a suspicious Shs600m land transaction in Seguku, Entebbe with a whistle-blower allegedly being fired from the organisation. He denied any wrongdoing." ${ }^{4}$ Further, it is reported that in 2014 that a wide section of CSOs were losing donors over transparency and accountability gaps.$^{50}$ It was indeed reported that many of the NGOs harbour fraudsters and embezzlers within themselves. Further, that the fraud is facilitated by lack of guidance manuals on procurement, fundraising, human resources management, risk assessment, anti-corruption, anti-fraud and poor internal accounting systems. ${ }^{51}$

This poses questions as to their functionalities and service delivery to the citizenry. In fact, it raises questions as to whether they are still relevant in light of the manner in which they currently operate. Accordingly, CSOs have failed to realise that good governance within themselves is important for a sector that is well informed and responsive to accountability demands. ${ }^{52} \mathrm{~A}$ factor that may partly cause compromise is that the level of corruption in CSOs is negligible for the monies involved in the fraud are not as huge as those in the government. Nevertheless, though negligible, it is corruption. It is a case that requires further investigation and forensic audits to ascertain damage and the extent of damage by CSOs in as far as accountability and transparency are concerned. Indeed, the established accountability mechanism, the QuAM initiative has so far established 23 district QuAM committees but does not provide comprehensive solutions to the accountability problems within the wider civil society. ${ }^{53}$ For instance, the NGOs have acknowledged that they continue to struggle with accountability in leadership, where the chief executive officers, executive directors or presidents and team leaders, want to solely remain leaders of the organisations for life. Arthur Larok has, for instance, stated that; "Accountability within NGOs is also a challenge. Few NGOs have seen the handing over of leadership. We see what looks like lifetime NGO presidents and we should take care not to become part of a patronage culture." 54

Based on the above, it is quite clear that while CSOs play an important role in criticising government, with the aim of quality assurance in service delivery, the face challenges that could undermine their work. Challenges are usually manifested in change of direction

49 Stephen Otage and Ivan Okuda, "NGOs losing donors over poor accountability - report", Daily Monitor, 30 June 2014, available at http://www.monitor.co.ug/News/National/NGOs-losing-donor s-over-poor-accountability---report/688334-2366126-48n46rz/index.html (accessed 13 October 2016).

50 Otage and Okuda, note 49.

51 Otage and Okuda, note 49.

52 Barr, Fafchamps and Owens, note 26.

53 QuAM, "Milestones", available at http://www.quamuganda.org/about-quam/milestones (accessed 1 April 2016).

54 Ministry of Foreign Affairs of Denmark, NGO Centre, available at http://www.netpublikationer.dk /um/11090/html/chapter05.htm (accessed 13 October 2016). 
in their work without informing the regulating authority and the infestation of corruption in financial management aspects such as embezzling monies and forging payments or cash payments with impunity. Corruption is also manifested in human resources management system in recruitment processes where nepotism features and over stay in leadership. The increasing poor accountability practices have in the recent past and the present times attracted government attention with the aim of ensuring that their activities are regulated. For instance, the former Internal Affairs Minister, General Aronda Nyakairima upon assuming office warned NGOs against engaging in activities than those they registered to do. ${ }^{55}$

\section{Lack of Proper Internal Control Systems}

There are proper internal control mechanisms within the civil society sector. For instance, so many registered organisations are "brief case" organisations. That is, they have no offices and do not have working staff whether temporal or permanent, yet they receive funding. In most cases, they are managed by an individual, who solely manages finances of the organisation and does not have anyone to report to. Moreover, there is no clear line as to how the money is spent and on what it is spent. As such accountability within the sector is lacking, the problem being aggravated by lack of poor financial monitoring systems and, therefore, poor financial performance. ${ }^{56}$ The problem also doubles with the CSO's incompetence to provide appropriate financial budgeting and reporting and, therefore, a low resource base arising from reduced opportunities for funding. ${ }^{57}$ Such instances have definitely prompted the government to regulate civil society with the aim of ensuring that proprietors do not corruptly or unfairly benefit from donors. Regulation is also aimed at ensuring that those with monies do not use money for subversive activities. ${ }^{58}$

\section{Survival Syndrome within Civil Society}

One of the major challenges hindering the growth of CSOs is individuals who do not want to handover the leadership of the organisation. They find them as a source of survival and a means of survival for their families. Moreover, in so doing, they do not account to anybody. They spend organisations' monies within their powers and whims. Such acts of entrenched,

55 Otage and Okuda, note 49.

56 See for instance Robert Oguti Etengu and Margaret Amony, Internal Control System and Financial Performance in Non-Governmental Organisations in Uganda: A Case Study of International Union for Conservation of Nature, International Journal of Contemporary Applied Sciences, Vol. 3, No. 2, February 2016, available at http://ijcas.net/Files/CMSUserOwnFolder/issue/February-2016/18.p df (accessed 20 December 2016).

57 Etengu and Amony, note 56.

58 See for instance Steven Ariong, "District says NGOs fighting female genital mutilation face closure", Daily Monitor, October 22, 2012, available at http://www.monitor.co.ug/News/National/NG Os-fighting-female-genital-mutilation-face-closure/688334-1538692-8c9hm6z/index.html (accessed 20 December 2016). 
administrative malpractices as well as nepotism, socialism and tribalism have left no option but for the government to regulate their operations.

\section{Duplication of Work}

Amidst governance concerns in CSOs, there is duplication of work by CSOs. ${ }^{59}$ An activity worth implementing by one organisation is usually implemented by various organisations. Duplication raises questions as to whether the existence of too many organisations doing the same piece of work is necessary. The government has accordingly come up strongly against duplication of work and the mandate of CSOs in as far as they perform similar tasks. Duplication of work leads to monotony and unjustified expenditure, too which government is sometimes opposed.

\section{F. The Battle Between Civil Society and State Interests}

Power relations between civil society and government have expressly shown that the two parties have specific interests they consider a priority For instance, the primary interest of the State is to ensure that its subjects receive the necessary services. The services are however based on meeting minimum standards. On the other hand, civil society aims at ensuring that in delivering services government does so effectively. Furthermore, civil society also complements government in delivering services to the citizenry. Nevertheless, in the recent past and the present time as noted above, civil society has fundamentally shifted from playing a complementary role in social service delivery to advocacy around government initiatives to meet citizenry needs and demands. ${ }^{60}$ Government faces diversity of challenges in trying to bring services closer to the people. Civil society in return always takes advantage of challenges faced by the government, usually manifested in criticism of a negative character. Resultantly, face-off between government and civil society has become eminent. It has accordingly become increasingly hard to strike a balance work of the two parties. It has indeed become more confrontational than complementary. The government no longer trusts civil society while the civil society has become politically critical of the government. To that extent, there is now nothing less that suspicion between the two parties, that what at play is how the interplay of politics and overlap of roles of the parties. The situation as described presents a challenge in how the two can effectively contribute to the needs of Uganda's citizenry.

59 See for instance Steven Ariong, "NGOs face closure in Amudat", Daily Monitor, 6 June 2016, available at http://mobile.monitor.co.ug/News/2466686-1175626-format-xhtml-w6pbyvz/index.ht $\mathrm{ml}$ (accessed 20 December 2016).

60 Devlin-Foltz, note 26. 


\section{G. Conclusion}

The operating civic space for CSOs in Uganda is constantly narrowing with government getting quite strict on CSOs' operations. The government has thus made the modus operan$d i$ for CSOs very demanding, with wide and extensive legal requirements, for which CSOs must comply with. Though government has an upper hand, CSOs are partly to blame for the shrinking space due to lack of clear and proper accountability mechanisms, corruption and over stepping their mandate from being complementary to government in provision of social services to heavy politicizations and overly criticism of the government without even acknowledging positive steps by government. Nevertheless, there is hope of harmonious and joint operations if CSOs and government can meet their respective duties and obligations.

\section{H. Recommendations}

In the prevailing state of affairs, it calls for the need of capacity building of CSOs to effectively counter increasing security threats. A primary strategy is to ensure that all CSOs are aware of the impending danger that comes with both old and new legislation if not complied with. Compliance with the laws is thus a strategy for which survival and sustainability of CSOs can be endured. Justification lies in the failure of attempts for non-compliance missions. CSOs fully compliant with the laws are usually hard to deal with from a restrictive perspective for they are hardly at fault within the law. Despite the fact that legal compliance is critical, it is also important to ensure that capacity for physical protection is built alongside legal compliance.

\section{Adoption and Strengthening of Security}

Security of CSOs needs to be strengthened through trainings and capacity building. Security should target safety measures for lives of civil society staff, security of information as well as of physical office premises. Thus far, CSOs should not fear to heavily invest in security of their staff, informational and premises. Likewise, security agencies especially the police owe the citizenry a duty to protect their lives and their properties. They should therefore ensure that they carry out investigations into security threats and problems to a conclusive process. They should as well put in place measures that would assure Ugandans of safety and security. They should work towards bringing impunity to an end.

\section{Co-operation and Solidarity}

In isolation, a CSO cannot achieve much in terms of self-defence. As such CSOs should adopt and build solidarity initiatives for a collective voice amongst themselves if they are to overcome threats from the State and other individuals or organisations. Solidarity will mean a united front to counter oncoming forces. It will also inform the formation of a favourable 
operational climate for CSOs. Thus, CSOs should venture into formation of loose coalitions as well as capacity building strategies such as information sharing. This will improve their working environment and modalities.

\section{Alternative Source of Funding}

One of the ideal solutions to the problem of reliance on donor funding is exploration into self-income generating strategies for CSOs. CSOs need to come together and think hard into sustainable advocacy and building of human rights work. Equally, most of the funding that comes to CSOs is tied to particular activities and, therefore, without flexibility in expenditure. The result is stunted institutional growth and development as there are usually no funds committed to them. It is thus imperative that CSOs explore into non-restricted sources of funding to ensure the promotion of institutional growth and development. It would also serve justice to survival of CSOs if income generating projects are delved into by CSOs as a means for raising monies to fund the activities of the respective organisations.

\section{Co-operation with the Government}

One way to work with government with minimal conflict is to both directly and indirectly partner with it. Partnership with government in citizenry engagement and service delivery builds healthy relations necessary for the smooth functioning as well as the survival of CSOs. It also affords some degree of protection to the partnering CSOs for it is rare that such CSO will carry out its activities without the knowledge of the State.

\section{Amendment of Legislation}

A strategy adopted by CSOs through advocacy and use of legislators to amend draconian legislation would go milestones in improving the operating environment of CSOs. For instance, CSOs can present private members bills through members of parliament with the aim of achieving a change in the legal regime. Some of the legislation that can be targeted includes the Press and Journalist Act, the Official Secrets Act, Cap 302, the Access to Information Act, 2005, the Public Order Management Act, 2013, the Anti-Terrorism Act, 2002 as amended in 2015, the Income Tax Act, Chapter 340, the Anti-Money Laundering Act, 2013, the Public Finance Management Act, 2015 and the NGO Act, 2016. Well-articulated and clearly thought out amendments to some of these laws will improve the CSO operating environment. 